\title{
SOCIALIST ROMANIA AND THE FUTILITY OF COLD WAR ANALYSIS
}

\author{
STEVEN G. RANDALL ${ }^{1}$
}

\begin{abstract}
This discussion looks back at socialist Romania and the collapse of the Ceauşescu regime. It suggests that Romania, like all states, socialist, socialdemocratic and neoliberal are confronted by the same world systemic capitalism and that all states use a mixture of policies involving both capitalist and socialist, democratic and authoritarian features in the attempt to avoid the hazards and to gain the advantages of a global system dominated by capitalist accumulation. Using a diversity of assets and hampered by limitations inherited historically, some will fail and some will succeed as state projects. Cold War era analysis will not be useful as a way to evaluate or predict winners or losers. Likewise, the failure of Communist Romania as a state system could not have been predicted either by its authoritarian or by its socialist policy features.
\end{abstract}

Keywords: communism, socialism, capitalism, neoliberalism, world-system, Cold War, democracy and authoritarianism, UMass Romanian Research Group

"The bourgeoisie cannot exist without constantly revolutionizing the instruments of production, and thereby the relations of production, and with them the whole relations of society. Conservation of the old modes of production in unaltered form, was, on the contrary, the first condition of existence for all earlier industrial classes. Constant revolutionizing of production, uninterrupted disturbance of all social conditions, everlasting uncertainty and agitation distinguish the bourgeois epoch from all earlier ones. All fixed, fast-frozen relations, with their train of ancient and venerable prejudices and opinions, are swept away, all newly-formed ones become antiquated before they can ossify. All that is solid melts into air, all that is holy is profaned, and man is at last compelled to face with sober senses his real conditions of life, and his relations with his kind."

(Karl Marx, The Communist Manifesto)

\footnotetext{
${ }^{1}$ Emeritus Professor at Temple University, Japan, e-mail: srandall@historic-deerfield.org.
} 


\section{I.}

This well-known quote, nearly Biblical in its poetic language, foretells of a time near the fullest expanse of bourgeois capital-a time when everything that describes the work of anthropologists in the here and now, that is every cultural, social, religious, racial, ethnic, sexual, environmental, national, political and economic variation found and documented among the diversity of people during the modern era, will "melt away" and become irrelevant-used, abused, and abandoned. Every human on earth will then be "compelled to face with sober senses" the fundamental maternal interdependencies between and among themselves.

How real could such expectations, in fact, be? It is possible even to describe what such a time (when all fundamental relations are revealed) would look like? Well, we must emphasize here, that ethnographic anthropologists, in point of fact, have only done fieldwork among people existing during the modern era-not among "old modes of production in unaltered form." We have observed some "fast-frozen relations" with "venerable prejudices" in the modern era-but we emphatically work, and have always worked, only among the modern, the "newly-formed ones," that, perhaps, are destined to "become antiquated before they can ossify," as many have already.

However, if we have done work in any modern place where "the bourgeoisie cannot exist," it would be where capitalists cannot themselves revolutionize production and relations of production, because that, according to what Marx and all modern entrepreneurs say, is a necessary condition of bourgeois existence. Such a place, without capitalists, was the major claim of the communist party of Romania. Or, to put it another way, how transformative and "revolutionary" was socialist Romania? How real was that claim, and even more, what difference would be being revolutionary make anyway?

Did not Romania need to earn hard US dollars and did it not have a national currency with some kind of exchange value? Did it not have to secure international loans form capitalist banks in good faith and profit margins so that loans could be paid back with interest? Did it not organize a nation-state and issue passports and visas? Was it not dependent on a balance of trade and a realist foreign policy requiring military hardware, industrial technology and resource inputs from other states, both capitalist and non-capitalist-just about like any other participant in the modern world's system of nations?

I would first like to portray my thoughts about Romania, and to make at last a feeble attempt to give substance to the near millennial vision of Marxthe one where there are no capitalists able to revolutionize technology and, thereby, social relations. I defined his Manifesto outline of capitalist globalism 
by comparing socialist Romania to both liberal and socialist states. I think that Marx has described this globalism in terms that are more Darwinian than dialectical. States of whatever genus and species are in a struggle for existence in an environment defined by capital. The latter determines who is adapted and who is not-but 99\% will finally become extinct, liberal or socialist, authoritarian or democratic, free market or planned. Only after the geological era made by capital collapses under the weight of its own dialectical contradictions will there be a chance for the real relations between people to be perceived. I will argue further that the time is short, and the hour late for human civilization.

I have had a long time to mull this over-several decades since our group of UMass anthropologists did their fieldwork under the leadership and direction of Prof. John Cole. (None of these contemplations, by the way, have been very much solicited by the academic world where I sought to make living so here are my general impressions of the mountain village of Fundata, where I conducted research). In the 1970s this beautiful Carpathian community, one of the Bran Castle villages, had all the features that demonstrate in a most dramatic way, the mutualism, reciprocity, and social solidarity that anthropologists have found in peasant communities throughout the world. This mutualism has served the villagers well. Villagers participated in an international solidarity with their place of origins. Many people would show me old photos of their early 20th century ancestors who had migrated for work in the industrial cities of Detroit, Michigan and Erie, Pennsylvania-both cities in the USA. Often, such migrant workers would return to the Bran area to reestablish their lives as farmers, bringing their savings from such industrial work. Others ran successful small business in the United States. I cannot forget the image of Domnul and Doamna Gavenia, dressed in business suit and gown typical of the 1920s USA. They were painted as a fresco on the back wall of the "new" church they had contributed the money to the villagers to construct. Holding in their joint hands, the couple present a small image of the church as a gift. The "old" church was not far from the larger "new" church. The former, being smaller, was used in the winter. The latter, being larger, was used in the summer. In the 1970s, the older ladies of Fundata still sported the hand spun and woven multi-colored costumes of Bran women. Made of wool from the very sheep they still raised, their crafts were also proudly displayed on the walls of their houses as tapestries, blankets, and decorative textiles. Such crafts, for personal consumption and not for tourists, symbolized the solidarity and common identity that joined families across the many different political regimes collectively confronted through time and over geographic space. 


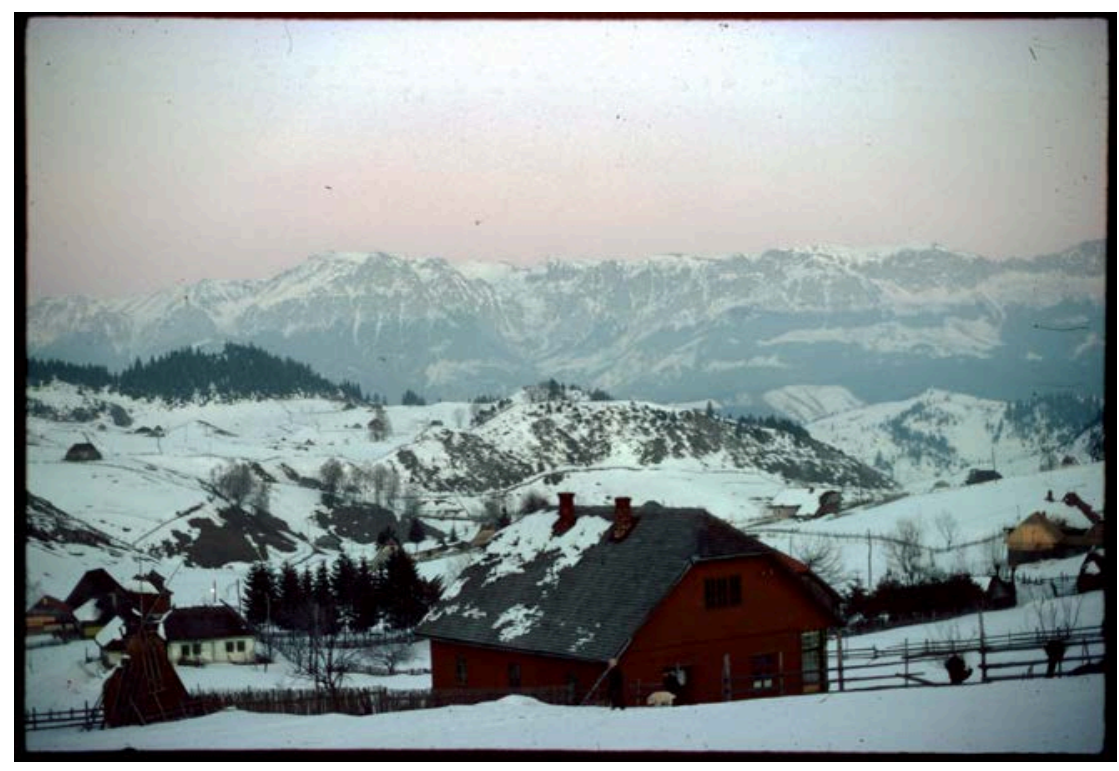

Fundata, Brașov County. Source: Author's archive.

I would like to start with some remarks about the limitations of ethnography in socialist Romania. I think there is reason to acknowledge some serious naïveté, which is well captured by the ambitious purpose and aim of our original project, "The Socialist Transformation in Romania." We had set about to study the emergence of something new, and indeed, socialist Romania was a solid, newly-formed place, which had also, alas, "melted way," (and long before it could "ossify") while, by contrast, the bourgeoisie was then and is now doing quite fine, if not better than ever by modern measures of class inequality, capital accumulation, and technical change.

So, did our work anticipate that Romanian socialism would be yet another "profaned" and "antiquated" set of relationships—and are we thereby "compelled" now, after its demise, to face the real conditions of life and our relations to each other in Romania and elsewhere? What did we imagine that ethnography would let us know about the "real conditions of life," and all human relations?

Many questions remain: Will more newly formed relations arise and melt before ossification? In the field, what should we have looked for, and what needs to be done now, and how much time is left to do it in? Must we anticipate yet another liberal democracy in Romania, a new member of the global market system, along with increasing class inequality and polarized ethnic diversity? Are these bourgeois social relations the only real material relations possible? 
Secondly, I would like to contemplate a thesis put forth by Katherine Verdery as she recounts her surveillance files collected by the Romanian state security apparatuses during the Ceaușescu regime-namely that:

...doing fieldwork in a communist country inserted the researcher directly into a global context, giving things a significance they might not have had elsewhere. An anthropologist in the field "behind the Iron Curtain" was a point at which global political forces intersected; anything she did could be interpreted in that light. (Verdery, 2018)

I agree with Dr. Verdery that ethnographic fieldworkers who have been educated at institutions on the noncommunist side of the "Iron Curtain" discover that their intentions are fraught with special "Cold War" suspicions when doing work on the communist side of the curtain. The monitoring, the intrusions into private moments, and personal relationships, and the propaganda like injections into her intellectual analysis, which she describes in minute detail, are objectionable. She was cast by national governments into politically charged situations, not surprisingly characterized as an epic clash of capitalism vs. socialism.

However, I will take issue with Verdery in one major respect. For her, the authoritarianism and near megalomania of Ceaușescu, the constant surveillance, the endless suspicions that she was spying on military facilities, while being a provocateur and Hungarian revanchist arise out of the very nature of socialism. Authoritarians are the special fault of communist state systems much more than within the Western world and neoliberal capitalism:

In the United States, the concept of transparency has a fundamental place in ideas about personal behavior, as well as in notions of democratic practice (though not, unfortunately, in the practice itself). This made living in a forest of secrets especially fraught for someone like me, at the time an unreflective believer in "telling it like it is." Secrecy was the essential medium of Securitate practices. It was also pervasive in all spheres of 1980s Romania, under the "wise guidance" of the Communist Party led by Nicolae Ceauşescu, whose rule had by then become an ugly dictatorship. (Verdery, 2018)

In contrast, I will suggest that every state is liable to become more or less authoritarian at some point during its life cycle. One dictatorship is much like another and all are the product of the same global system we have been living in for some few centuries during the modern era-one long cycle of fast frozen relationships, melting one after the other, all attempting either to capture some benefits through, or to escape in some way from, the logic of the same world capitalist system, as per Immanuel Wallerstein's world-systems analysis - a single system all are subjected to (Wallerstein, 2018). 
Certainly, as Verdery implies, Western capitalist societies do "not always consistently" adhere to the core values of "personal transparency" and "democratic practice," but still, somehow they try harder than do the communist states. I suggest, on the contrary, that the "liberal democracies" protest too much, even as the obvious must be granted: that "iron curtain" states during the Cold War did not display more than superficial resistance to authoritarian rule. There is evidence enough, however, that the nations are not only unequal in their variant capacity to engage in a global game of monopoly, but also unpredictably duplicitous and/or waffling (all of them in the world) in their commitments to political democracy, transparency, ethnic equality and social welfare.

II.

To begin, then, with our ethnographic naïveté in communist Romania: When we set out to do fieldwork there, none of us had any qualms or doubts that we were observing "socialist transformation" and that this research was going to reveal something about the politics, methods and goals of communismthat is the essential character of a communist state. Items such as the use of planning in organizing production, the industrial development of the country, the outlawing or marginalization of markets, profits, and private property, (in preference to collective property, as with the collective farm), the one party embodiment of the "dictatorship of the proletariat" and policies designed to end class, ethnic, gender, racial and religious distinctions would reveal themselves as successes or failures. We would emerge after fieldwork with some knowledge about what could lead policy in a socialist direction and what could not.

This list of "essential communism" is not meant to be complete, nor is it strictly accurate, since many states identifying with socialism or communism during the 1970s did not completely institute or fully subscribe to everything on the list. Lists often differ practically and theoretically. Sometimes this has to do with differing methods and stratagems for building socialism and communism, and sometimes it represents differing compromises and capabilities relative to the realities of socialist transition in a world still largely dominated by global capitalism, neoliberalism, and powerful military opponents bent on opposing any communist/socialist alternatives. (I cite as examples along these lines the large non-collectivized farming of communist Poland, the worker self-management of the former communist Yugoslavia, the international isolation of communist Cuba and North Korea, China's embrace of a "free market" stock market, and Romania's independent economic and foreign policy relative to the Warsaw Pact.)

No socialist state has ever been able to proceed in an unrestricted manner. As a broad policy choice, it is not an easy thing to create a place where capitalists, money, and markets are out of the picture. However, beyond the 
variations and disputes regarding the way toward post capitalism, I would like to suggest something more. Neither are the states claiming the legacy of liberal capitalism able to make the world wholly as they would as well. They too must suffer the difficulties of the bourgeoisie even as they embrace them-and the more they embrace them, the more constrained they are.

All states, most importantly, are constrained by the dead weight of history and by what has gone before, still ongoing and still dominant in the here and now-rendering everyone of them witnesses to the reproduction of bourgeois accumulation:

Men make their own history, but they do not make it as they please; they do not make it under self-selected circumstances, but under circumstances existing already, given and transmitted from the past. The tradition of all dead generations weighs like a nightmare on the brains of the living. And just as they seem to be occupied with revolutionizing themselves and things, creating something that did not exist before, precisely in such epochs of revolutionary crisis they anxiously conjure up the spirits of the past to their service. (Marx, 1994)

In this case, the "circumstances existing already" describes the capitalist world-system - the very system constantly revolutionizing bourgeois production, "and thereby the relations of production." If Marx's poetic description of the situation is correct, then both liberal and socialist states are, in some very similar way, "not able to make the world as they please."

What might result, therefore, if we relaxed the distinctions, not only between one communist state and another, but also between the "liberal" West and the "socialist" East? I don't intend to argue that there is no substance to the distinction between "free market" capitalism and socialism. I do intend to suggest that no single nation state, of whatever formal type, is in a position to remake themselves any way they please. There has been much exaggeration, a product of the Cold War perhaps, regarding the powers of even the most powerful of such states as, for example, the United States.

Should this be the case, and I argue that it is, many of the differences between them cannot be essential, by which I mean, uniquely a feature of socialism or liberal capitalism. Both will have recourse to authoritarians, both will employ a smaller or larger percentage of options from the same grab bag of policies that include, planning, markets, private property, socialized property, social welfare, wage labor, monetary manipulation, managed trade, free trade and international trade, to name a few.

There will be at least some capitalism within any socialist state and at least some socialism in every capitalist state. Both will "anxiously conjure up the spirits of the past to their service"-in the form of broadly similar institutions, as in the following examples of settlement, agriculture, and money. 


\section{Settlement Planning}

It is possible to discover everywhere on the "free market" side of the former Iron Curtain public/private partnerships imposing urban planning schemes upon an unwilling population in a manner not unlike Communist Romania's centrally planned urbanization, known as systematization. Sistematizarea called for the doubling of urban centers and the elimination of remote villages with populations under 1000 . This planned settlement policy, however, went well beyond the upgrading of small towns into true urban centers. It also sought to transform villages and redesign their role in regional economies.

For example, in the village of Fundata, the plan called for the creation of a sat turistic, that is, a tourist village. This would require the dispersed settlement pattern of Fundata to be transformed into an increasingly centralized community, in contrast to the needs of peasant mixed farming and sheep transhumance. In place of the traditionally dispersed settlement pattern, the village would eventually become more visually commodious and more responsive to the needs of seasonal tourists-who, presumably, did not wish to hike over kilometers between traditionally isolated farmsteads, where they might find "bed and breakfast" like accommodation. The new urban working classes would be drawn to the striking Carpathian vistas but, in theory, they did not want too much exercise.

Moreover, investment in infrastructure, such as electric lines, sewage systems, and indoor plumbing would be facilitated by a more dense concentration of the village. According to Sistematizarea, as the villagers themselves transitioned out of unmechanized mountain agriculture, they could concentrate on local tourism and/or commuter employment opportunities, facilitated already by the major highway that runs through the Bran pass.

It was difficult for me to measure how rapidly, in actuality, this settlement transformation was taking place. The better housing, cantina, and commune office where along the highway in a center. These buildings were electrified but there was not then, in the 70s, indoor plumbing. Most of the village seems barely to have concentrated at all.

Most of the villagers were dispersed over a large area, practicing traditional transhumance, complete with shepherds in classic woolen capes, (who managed the consolidated flocks of sheep). In addition there was smallscale household horticulture, along with cattle and dairy farming, sustained by hay harvests from the many traditional pastures. Each household would contract to deliver cattle, wool and sheep in numbers consistent with the targets of government planners. There were penalties for failure to meet plan targets and incentives for fulfilling them. How these deliveries were to be met was wholly desegregated by landholder and managed by each household, according to their individual contracts with the state. The village as a whole, however, would reap the consequences of plan fulfillment or failure. 


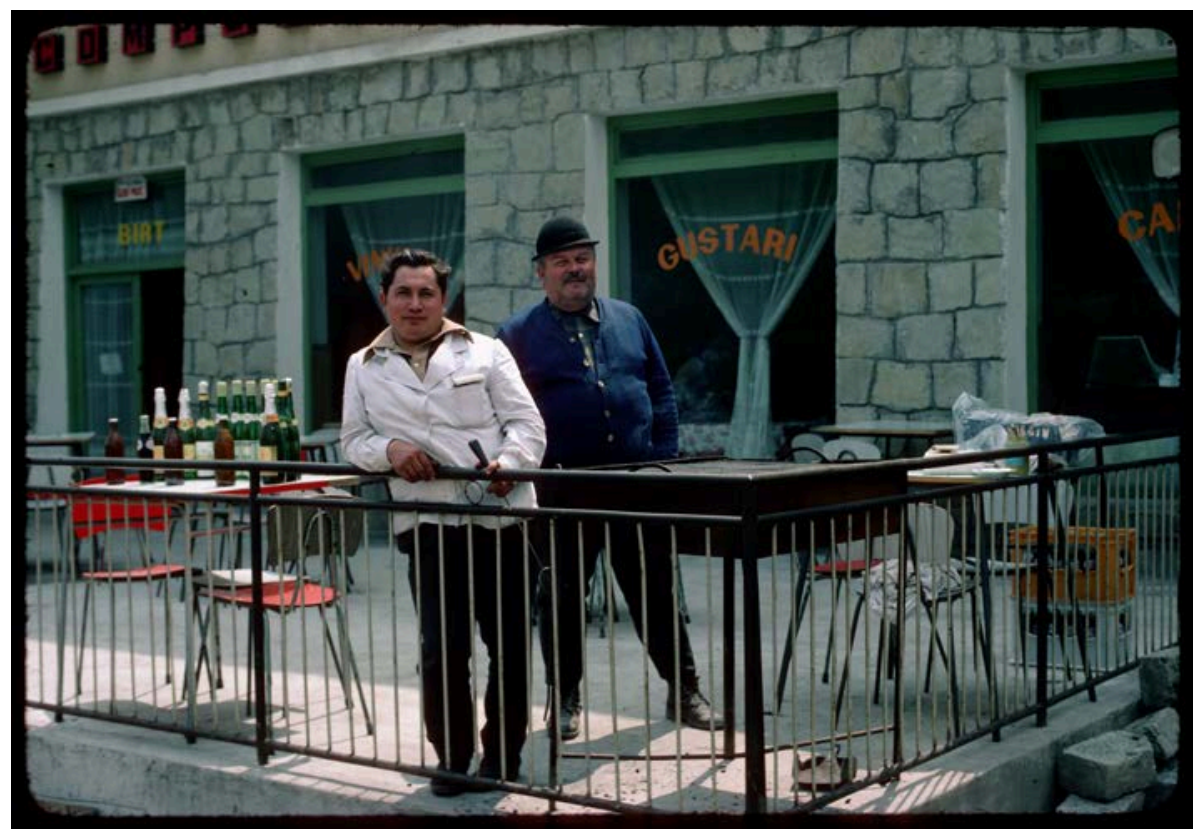

The cantina. Source: Author's archive.

Keeping up production with traditional labor-intensive methods, centuries old, conflicted with the Sistematizarea plan to transform the village into a tourist facility. I could not detect much evidence for centralization, even as each plan year formally called for slowly constricting the circle outside of which new farmstead buildings were to be prohibited. While the better looking and newer homes did seem to be concentrated along the highway, this seems largely to have been determined by the circumstances and personal choice of each household.

The comparison I wish to make here concerns how nearly identical settlement planning seems to be in any industrial state. Labor forces of appropriate kinds in all cases must be relocated-the wrong kind moved out and the right one moved in. Locations and infrastructures are historically inherited, and so settlement planers must accommodate changing industrial and postindustrial technologies.

Whatever the distress of displaced Romanian villagers, their unhappiness are not unlike those discontents, for example, caused by the rapid gentrification of Oakland-planned by Apple, Facebook, Cisco, Intel, Hewlett-Packard, Oracle, Yahoo, Alphabet, and Google in California's greater Silicon Valley. Both systems 
of urban and rural planning, neoliberal and socialist, tend to be grandiose and bureaucratic. Both neoliberal and socialist states have been accused of ethnic and class bias. (See "Mapping Dispossession, Mapping Affect" by Manissa Maharawal and Erin McElroy, Anthropology News, November/December 2018, pp. 17-21).

\section{Industrialized Agriculture}

The gigantic industrial farming and land consolidations of American agroindustrial farming is hardly less ambitions, resource irrational, and stressful than the imposed level of collectivized agriculture in socialist Romania. A review of the literature (Kideckel, 1983; Kligman and Verdery, 2011; Iordachi and Bauerkämper, 2014; McIntyre, 1993; Tauger, 2004; Xu, 2013, 2018) on collective farming, under socialism in Romania and in other socialist states, does not produce, at least to my mind, a clear consensus on the superiority of American, Brazilian, or Canadian big farming over Soviet style or Chinese style big farming. The industrial production of beef in Britain or the USA is destructive of land and resources, and can hardly be seen as an improvement over conditions in Romania. (See "Industrial-scale Beef Production is a Sign of Crisis in Britain's Farming," Guardian 2018.) Moreover, large scale and small-scale farmers throughout the world experience very similar levels of economic instability and emotional distress. In Japan, in Africa, in Brazil, in Peru, in India and in the USA (to name just a few) farmers demonstrate and require state intervention. This situation is summed up well in "Why are America's Farmers Killing Themselves in Record Numbers?" (Guardian 2018):

The US farmer suicide crisis echoes a much larger farmer suicide crisis happening globally: an Australian farmer dies by suicide every four days; in the UK, one farmer a week takes his or her own life; in France, one farmer dies by suicide every two days; in India, more than 270,000 farmers have died by suicide since 1995.

Both capitalist and socialist systems of agriculture are constrained by the same fossil fuel technology, by the same economies of scale, by the same environmental externalities that make available the same mass of surplus value that can be invested in other priorities outside the welfare of farm labor. The world system is a capitalist system and within it, states have only begun to investigate what a sustainable farming technology would look like. Few have a clear picture of what the role of farm labor would be in such a system, or what role nations states would play in food security. 
Industrialized agriculture globally, relies, nevertheless, on diverse forms of sweated labor. An example, in the Romanian case, would be "patriotic work" (munca patriotică), mobilized particularly at harvest time during the Ceaușescu era. It was directed by local governments and was less than voluntary. Urban dwellers and other non-agricultural citizens would not be compensated for fieldwork they were often ill suited for, nor were the working conditions ideal. I don't have a good hold on how necessary such state solicited labor mobilizations were, nor how effective. They are often of short durations.

In the mountain village of Fundata, were I did my research, agricultural work was not collectivized. At peak periods in the agricultural calendar, such as when the haying must be done with traditional scythes, household labor was supplemented by extended household members who were absent from the village most of the time-employed elsewhere in logging or industry. Such individuals were quite well equipped to do this intensive work, having been raised in peasant households. A regime of generalized household reciprocity seemed to me then to have been mutually beneficial for all concerned.

The point I wish to make here, however, is that sweated labor is a necessary component of industrialized agriculture, weather by big private land owners in, say California, or by big mechanized collective farms in Romania. Massachusetts, the US state where I now reside, is not known for its agriculture. Nevertheless, masses of seasonal migrants from Jamaica arrive to harvest cucumbers and apples. Even large dairy farms in Vermont require temporary labor to handle mechanized milking machines. The conditions for such workers are also much less than just. The workers must travel seasonably over long distances.

In some sense, this is similar to the family members who show up in Fundata during peak demands for labor. Most of the time, on a day-to-day basis, work in Fundata was feminized and supplemented by older family members. Whole classes of male labor and younger people, absent most of the time, would show up on weekends or seasonably. These mostly absent individuals were employed as wage earners far from village.

Anthropologists have long noted that traditional, labor-intensive agriculturalists (even in ancient times) could produce significant surpluses beyond their personal needs. These surpluses supported ancient elites and could still be used in socialist Romania to supplement the industrialized agricultural sector with a mountain version of sweated labor-used both in urban wage work and rural surpluses from traditional peasant style farming.

It seems that the more global industrial, commercial and large-scale agriculture becomes, the more marginalized agricultural workers and work become. 


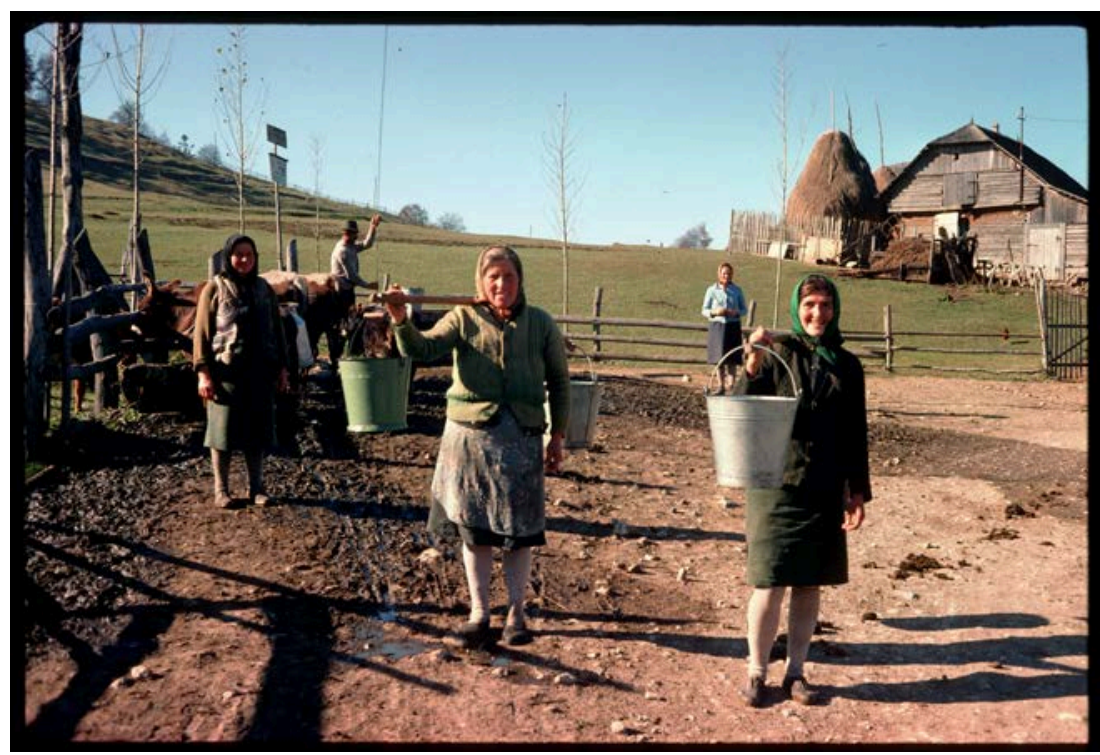

Villagers at a well. Source: Author's archive.

Collective, traditional small scale mechanized family farming and migrant-labor dependent agricultural production have served, in places like socialist Romania, China and Poland (and really everywhere) as vast unenclosed spaces where surplus labor can find employment. Enclosures and privatization throughout history have resulted in displaced and urbanized new worker classes.

\section{Money}

The role of money is political, and incidentally economic, to say the leastboth Western style banking and socialist Romania's constraints on the private ownership of "hard currencies," particular the US dollar, appear to proceed from the same underlying suppositions, however they differ in specific detailsreflecting more the relative bargaining position of rich creditor nations versus credit dependent nations. Though some socialist states have claimed otherwise, clearly few if any socialist states have ever measured work and compensation in accordance with Marx labor theory of value. This is because they cannot secure loans, pay off debts, export or import products, gain licenses to patients or pay for embassy personnel without following the rules of capitalist banking in some fundamentally capitalist way. This fact has significant consequences for all states, socialist and liberal. 
In Fundata, people pressured me, an American, to buy things for them in the "dollar shops," where the best consumer items were to be found. Romanians were not legally allowed to own hard currencies and where not able to enter such shops without someone legally in possession of US dollars. This fact is well known. There was a popular refrain during the 1970s to the effect that "if it's good, it's for export." These times, when I was doing fieldwork in Fundata, were, moreover, the good times for post-war Romanians-it must be noted. Conditions would get much worse.

The Romanian leu was not then a fully convertible currency. It was used by the locals but not greatly by international bankers. Inevitably some Romanian lei would escape into the Western banking system where one could exchange dollars for much more lei (illegally by Romanian law) than the rate allowed within the country. National policy then was directed toward earning US dollars and other hard currencies-in an effort to pay off loans, fund imports, and construct an atmosphere of trust suitable to the priorities of their Western trading partners. Such jousting between soft and hard currencies, we should recall, is not something "hard" to find examples of in other non-socialist nation states as well. The IMF and World Bank institutions were and are busy telling other "subordinate" states how to secure credit, pay off their international obligations, and restrain social welfare in favor of debt repayment.

During the 1970s, cavorting with the global institutions of liberal banking and finance had major consequences for Romanians, both politically and economically-becoming devastating during the 1980s. At the same time, one must emphatically acknowledge the impact of Ceaușescu's harsh currency measures and the devastating austerity he thought to be a necessary requirement of debt repayment. This austerity seems to be a major factor in the fall of the regime in 1989. We cannot justify the measures that Ceauşescu had imposed, nor the authoritarian powers which enabled him, but we should recall the austerity policies were favored by the dominant Western institutions also.

There appears to be a general consensus regarding Ceauşescu and Romanian communist history, which divides into two periods: the time between 1965 and 1971, and the time between 1971 and 1989. In the first period, there was a more open policy towards Western Europe and the United States. This allowed the regime to maneuver with flexibility and to move away tangentially from the Warsaw Pact signed during the Cold War. In the West, Ceauşescu became the "flexible" communist leader and favorite persona of US Republican presidents.

This better period is characterized, also, by the greater Communist Party stress on improving people's personal comfort. Investments were allocated towards building flats so that citizens could own a private residence in one of the many communist era high-rise buildings. Of course, primary and higher education, employment and healthcare were public welfare measures available to all in need-both urban and rural. 
I can describe my limited observations of rural health care. When my wife and I lived in the mountain village of Fundata, we spent occasional evenings with the family of the local GP and dentist, a married couple, and their young son. From them we came to understand some fragments of the local health care system. Both the GP and the dentist had received their education free, but also in exchange for a commitment to spend a certain number of years serving in a small rural setting such as Fundata. As part of his job description, the GP was also required to do rounds out to the more remote households on a regular schedule-transportation provided by horse drown vehicle. In short, professional people could not congregate solely in the urban centers where amenities were more available.

In addition, during this more commodious period, there seems to have been a measure of cultural flexibility and economic stability. In schools, Romanian and world literature substituted Soviet literature. Certain cultural figures were rehabilitated-for example, the right-wing historian Nicolae Iorga and Eugen Lovinescu, a modernist literary historian and novelist. Furthermore, however one may judge the functionality of communist Romania's full employment provisions, every citizen did have the legal right to a job (though, at times, was punished for unemployment without cause). Full employment is something that most liberal nations have not been able to sustain. The United States, for example, has not been able to provide for it, even after two very popular legislative attempts were made, first in 1945 and again in 1974. The failure of these initiatives was due largely to opposition from the Republican Party and conservative business interests (Goldberg, 2018). Yet, what is most interesting, in this context, is how both liberal and socialist states turn toward very similar social guarantees: full employment, in all cases, must depend on state led initiatives.

The relative flexibility of the early period began to unravel after Ceauşescu visited other communist states in 1971-such as People's Republic of China, North Korea, North Vietnam, and Mongolia. The total loyalty to the leaders of these countries, personality cults they were called, deeply impressed him and Ceaussescu began to imagine an expansive transformation of the nation - the creation of a new socialist human being.

Extreme nationalism, the deterioration of foreign relations with Western Europe and the Soviet Union and Ceaușescu's slide into something like megalomania highlight the stresses of the second period-culminating in the fall of the regime in 1989. This period would see power at the top increasingly concentrated into the hands of Ceaușescu's personal family members, including his wife Elena. 
Construction of massive buildings such as the House of the People, and poorly planned initiatives such as the Danube-Black Sea Waterway, joined other heavy industrial, but overly ambitious projects. These projects showcased Ceaușescu's vision of the "multilateral developed person" (omul multilateral dezvoltat). They also drained resources-moving the country into an international debt crisis of tragic proportions.

The regime decided to pay off the accumulated debt in one massive initiative, beginning in late 1980. The range of items selected for export (in exchange for hard currency needed to service debt) was truly draconian. Food shortages were commonplace and in October of 1981, a decree declared that those who purchased food exceeding one month of household requirements would risk imprisonment for one to five years. It is doubtful that this extreme austerity and debt service did much to help the Romanian economy. It was a great help to Western bankers, however. Without going into all the tragic details, extreme damage was done to the civilian population, to the social services and welfare provisions of the country, and to the stability of the regime. It would end, as we know, with the death by firing squad of Nicolae and Elena Ceauşescu.

Will states of any stripe in the world system abide by Economics 101 rules should their monetary system and trading structures face domestic or international disadvantage? Certainly the history of the United States and socialist China does not seem to suggest that they do. In a most amazing flip, it is currently the USA that seeks protectionism, while communist China becomes the most vocal defender of "free trade." What is even more interesting to me, in any case, is the apparently loose relationship between factors: Authoritarian figures, the ideological commitment to capitalism or socialism, the focus on market versus plan, strong or weak democratic institutions, systems of banking and credit-no single item on this list, alone or in combination, is a very strong predictor of the economic and political success of a given nation. Consider the contrasts between Cuba, China, North Korea, Vietnam, Chile, Greece, Saudi Arabia and Taiwan to name just a few. Each of these states has a unique combination of capitalism and socialism, while at the same time, some of the most authoritarian have experienced "success" while some of more democratic have experienced "failure." What can we say about Romania?

\section{III.}

As a final note, we must regret, as Verdery so effectively does, the loss of "transparency" in socialist Romania. But we must also admit that the spying and the Securitate bureaucracy of Romania has been surpassed in every way by the security apparatuses of USA, (MacAskill and Hern, 2018) and most Western 
nations, and also by the prying social media with their detailed data sets documenting aspects of our private lives down to our separate preferences for everything from underwear to reading material-which it privatizes and sells to political and commercial manipulators, as notoriously demonstrated by the Cambridge Analytica case (Solon, 2018).

These days, the common constraints and advantages of global capitalism are recognized widely, especially within the wealthy liberal states, but also by socialist states such as Cuba, North Korea, and Venezuela and emerging states in Africa, Latin America, the Middle East and Asia. Jobs migrate to China, desperate columns of ethnic migrants stream across Western borders (while overaccumulated money bags of capital stream across Eastern borders or hide on lawless offshore islands). Labor arbitrage pits the living wage against global sweatshops, corporations require lower taxes, free from environmental regulation, even as property concentrates wealth more than at any time in history.

Needless to say, there has been a plethora of assessments and reassessments of centralized, market, and bureaucratic socialist systems, focused on the structural failure of socialism as an idea and program. Western capitalist intellectuals have been producing formal critiques of planning, egalitarian goals, grassroots democracy, and class as the basis of revolutionary transformations since the very origins of the Red scares and the Russian Revolution-if not before. The Cold War has a long history. Socialism is characterized, in these models, as inherently infeasible for any complex industrializing society and its collapse as a program in any state is therefore understood to be inevitable and unavoidable. Authoritarians in Romania, East Germany, the Soviet Union, Cuba and beyond must exist because irrational socialism cannot exist. There have been many confrontations between heavy weight intellectuals along these lines. We mention only one example, the famous debate between Paul Sweezy (on the socialist side) and Joseph Aloïs Schumpeter during the winter semester of 1946-47 in Harvard's Littauer Auditorium before a packed audience. Here was a clash between the ideas of Sweezy's The Theory of Capitalist Development and Schumpeter's Capitalism, Socialism, and Democracy - both recently published in 1942 (Foster and Sweezy, 2011). Today, given the context of environmental and climate destruction, Schumpeter's notion of "creative destruction," the principle virtue of capitalist entrepreneurs, must sound cruelly sardonic.

In and about the mid-1970s and later, works on the irrationality and infeasibility of socialism took quantum leaps. Appearing about this time there were also innovative works by native East European intellectuals that added new analytical models framing the failures of socialism. They seemed to favor the successes of the market and private property-adding newly minted support to the standard liberal claims on democracy and freedom. This flurry of activity 
happened just as the Keynesian New Deal floundered in the West, Soviet and East European socialism began its painful collapse, and a new level of neoliberal globalism sought after the cheapest labor sources, the most open financial markets, and the fewest environmental regulations.

With some hesitation, I mention two Hungarian intellectuals who exemplify this latter trend: sociologist Iván Szelényi and economist János Kornai. Szelényi first came to my attention as our Romanian Studies Group discussed his book The Intellectuals on the Road to Class Power, published in English in 1979. In this work, socialist Hungary is presented as an example germane to socialist projects generally. Far from overcoming the class conflicts of capitalism (owners and workers) socialist states have merely transferred the powers of capitalist owners to a new class of intellectuals (professionals trained at institutions of higher education) who are privileged to direct the means of production (often to their own advantage) while workers remain disempowered. Kornai first came to my attention during a visit to Hungary with other American academics in 1989. He embraced the main context of capitalism versus socialism in relation to the notion of "budget constraints" and his ideas are conveniently introduced in his article "Hard" and "Soft" Budget Constraints' (Kornai, 1980). Hard constrains are thought to keep enterprises in the capitalist West within bounds. They cannot command more of a country's resources than their business success allows them. Beyond that, they simply go out of business. Socialist enterprises, on the other hand, being controlled by intellectuals, are unbound by soft constraints. These socialist enterprises are led by ideology and know nothing of bounds. Should they monopolize the resources of a country beyond viability, the state simply provides more resources by diverting them from other national resources-to the deficit of working people.

It is clear that some kind of relationship exists between Szelényi and Kornai's ideals that focuses on the "new class" basis of the planned economies. I only wish to point out here that if intellectuals and soft budget constraints are, and haven been, a problem for socialist nation states, they are and have been also problems for capitalist nation states. We do not have the space here, but readers will be familiar with the many powerful "think tanks" in the United States directed at providing "new class" direction to state policy. Business school versions of Samuelson's Economics 101 remain as the ticket to a middle class career in both government and business. These intellectuals are elements bound together into a "military industrial complex" - as firmly as organic chemistry can achieve. If, moreover, socialist states have "soft budget constraints," they are hardly more fungible than in the industrial West, where the big bank and auto industry bailouts of the United States and Europe have saved neoliberalism from 
itself. In the United States, there is a long history here-going back, at least, to the 19th century robber barons who required state support for infrastructure such as the railroads (Perlman, 2006).

If the similarities between states, socialist and capitalist are, should we say, "too comparable," then I question how much mileage can be had by treating them, in a sense, as unique brands with generic irrationalities. There seems to be no reliable way by which socialist versus capitalist state types can be utilized to predict which of the two will fail as a project. China's socialist aspirations are paired with an emerging elite depend on private property, personal wealth accumulation, and a stark market. It is interesting to note, in this context, that China's GDP growth, despite the "Great Leap Forward" and the "Cultural Revolution," was, over all, higher than in the USA and just about as high as it is today. Indeed, in an important sense the basis for the current market-oriented expansion in China was determined by the previous Maoist expansion (Long and Herrera, 2018). At the same time, both Cuba and China have been rather authoritarian with personality cults of their own, but their economic and social achievements, in some areas, put several Western liberal states to shame.

Does not the United States have a personality cult in President Donald Trump? Does he not trust in his family members in much the same way that Ceauşescu did? What about democracy? John Bellamy Foster's discussion of Trump's neo-fascist tendencies describe a severe crisis of neoliberalism not socialism: "Everywhere, neoliberalism has come to stand for polices of austerity, financial speculation, globalization, income polarization, and corporate cronyism" (Foster, 2017).

It is time to put aside much of the literature which has identified socialism and communism as irrational ways to promote industrialism and a classless society based on planning and/or so called "market socialism." Romania is simply another example of an attempt to live in a world confronted with the common threat of capitalist accumulation on a global scale: a world system, which has now reached a feverish pitch by creating an unprecedented environmental disaster, the Anthropocene, thereby suggesting the very end of human life itself (Ellis, 2018).

U.S. President Trump and his European admirers on either side of the former Iron Curtain are manipulating the once self-righteous whereabouts of democracy. He would fain "Make America great again" but for the elimination of criminal Latin Americans, terrorist Middle Easterners and "liberal mobs." A growing proto-fascism is crated daily in the USA by the inflating influence of the extreme right in other nations - each with their own version of nationalist chauvinism (see "What to Say to White People," by Steve Phillips, The Nation, $11 / 27 / 2018$ ). In a review essay, very regretful of unrequited liberal democracy, Sheri Berman discusses the failures of so-called democratic liberalism: 
Liberal democracy has faltered in Eastern Europe, is threatened by populists in Western Europe and the United States, and is being challenged by resurgent authoritarian in Russia, China, and elsewhere. Reflecting these trends, scholarship and commentary has become consumed by debates about "illiberal democracy," "global authoritarianism," and democratic "deconsolidation." Summing up what has become a widespread view, Victor Orbán, Hungary's current prime minister, recently proclaimed: "The era of liberal democracy is over." (Berman, 2018)

What of now in Romania? This is another discussion we must have, but note that neither Mihai Verga in Worker Protests in Post-Communist Romania and Ukraine: Striking with Tied Hands (2014) nor Alexander Clapp in his remarkable piece in New Left Review, "Romania Redivivus," finds much of the transparency that we all crave for in these post-communist states. In regard to ethnic tensions in post-communist Romania, there remains much that must be resolved, particularly between Romanians and Hungarians (Sigheti, 2013). Gypsies in post-communist Romania have not been treated impartiality according to most reports, while the movement of Romanian Roma toward Paris and London have reviled ethnic prejudice there as well (Taylor, 2013). The Romanian nation state and all these social relations, as Marx would describe them, are either "ancient and venerable prejudices" or newly minted "fast-frozen relations"- simply useful instruments or inconveniences promoting or inhibiting the accumulation of capital-none of them fundamental to the "real conditions of life," as Marx would have it.

At this point in history, we are not yet "compelled to face with sober senses", as Marx has phrased it, our "real conditions of life" and our "relations with" our "kind." This is a sad thing given that the IPCC has given us only some 12 years to do so in the face of grave climate catastrophe and the possible termination of modern civilization. The hour is late and the consequences of capitalism's limitless accumulation, resource depletion, global domination, and environmental destruction are nearing game over. The problems confronting nations on either side of the "iron curtain" are the same for all, as are the solutions.

\section{REFERENCES}

Berman, Sheri. (2018). How Liberalism Failed. Dissent, Fall: 119-123.

Clapp, Alexander. (2017). Romania Redivivus, New Left Review, 108 (Nov/Dec): 5-41. Ellis, Erie C. (2018). The Anthropocene: A Very Short Introduction. New York: Oxford University Press. 
Foster, John Bellamy and Paul M. Sweezy. (2011). On the Laws of Capitalism. Monthly Review 63 (1).

Foster, John Bellamy. (2017). Trump in the White House: Tragedy and Farce. New York: Monthly Review Press.

Goldberg, Gertrude Schaffner. (2018). Trying Again for Full Employment. Dollars and Sense 339 (November/December): 7-13.

Iordachi, Constantin and Arnd Bauerkämper. (2014). The Collectivization of Agriculture in Communist Eastern Europe: Comparison and Entanglements. Budapest: Central European Press.

Kideckel, David, A. (1983). Secular Ritual and Social Change: A Romanian Case. Anthropological Quarterly, 56 (2): 69-75.

Kligman, Gail and Verdery, Katherine. (2011). Peasants under Siege: The Collectivization of Romanian Agriculture, 1949-1962. Princeton, NJ: Princeton University Press.

Kornai, János. (1980). "Hard" and "Soft" Budget Constraint. Acta Oeconomica, 25 (3-4): 231-246.

Long, Zhiming and Rémy Herrera. (2018). The Enigma of China's Growth. Monthly Review, 70 (7): 52-62.

MacAskill, Ewen and Alex Hern. (2018), June 4. Edward Snowden: 'The people are still powerless, but now they're aware'. The Guardian.

https://www.theguardian.com/us-news/2018/jun/04/edward-snowdenpeople-still-powerless-but-aware?CMP=Share_iOSApp_Other

Maharawal, Manissa, and Erin McElroy. (2018). Mapping Dispossession, Mapping Affect. Anthropology News website, November 9, 2018. DOI: 10.1111/AN.1038

Marx, Karl. (1994). The Eighteenth Brumaire of Louis Bonaparte. Moscow: International Publishers Company.

Marx, Karl and Frederick Engels. (1998). The Communist Manifesto: A Modern Edition. London: Verso.

McIntyre, Robert. (1993). Collective Agriculture in Eastern Europe and the Former Soviet Union. Monthly Review, 45 (7).

Perelman, Micheal. (2006). Railroading Economics: The Creation of the Free Market Mythology. New York: Monthly Review Press.

Phillips, Steve. (2018). What to Say to White People. The Nation. https://www.thenation.com/article/democrats-midterm-voters-white-people/

Schumpeter, Joseph. (1942). Capitalism, Socialism and Democracy. New York: Harper and Brothers.

Sigheti, Radu. (2013). Romania's Ethnic Hungarians March to Demand More Autonomy. Reuter's. https://www.reuters.com/article/us-romania-hungariansidUSBRE92E0RY20130315

Solon, Olivia. (2018). Cambridge Analytica Whistleblower says Bannon Wanted to Suppress Voters. The Guardian.

https://www.theguardian.com/uk-news/2018/may/16/steve-bannon-

cambridge-analytica-whistleblower-suppress-voters-

testimony?CMP=Share_iOSApp_Other 
Sweezy, Paul M. (1942). The Theory of Capitalist Development: Principals of Marxian Political Economy. New York: Monthly Review Press.

Szelényi, Iván. (1979). The Intellectuals on the Road to Class Power. New York, Harcourt Brace Jovanovich.

Tauger, Mark. (2004). Soviet Peasants and Collectivization, 1930-39: Resistance and Adaptation. The Journal of Peasant Studies, 31 (3-4): 427-456.

Taylor, Jerome. (2013). The Truth About Romania's Gypsies: Not Coming Over Here, Not Stealing our Jobs. The Independent.

https://www.independent.co.uk/news/world/europe/the-truth-aboutromanias-gypsies-not-coming-over-here-not-stealing-our-jobs-8489097.html

Varga, Mihai. (2014). Worker Protests in Post-communist Romania and Ukraine: Striking with Tied Hands. New York: Manchester University Press.

Verdery, Katherine. (2018). My Life as a Spy: Investigations in a Secret Police File. Durham, NH: Duke University Press Books.

Wallerstein, Immanuel. (2004). World-Systems Analysis: An Introduction. Durham, NH: Duke University Press Books.

Weingarten, Debbie. (2018). Why are America's farmers killing themselves? The Guardian.

https://www.theguardian.com/us-news/2017/dec/06/why-are-americasfarmers-killing-themselves-in-record-numbers?CMP=Share_iOSApp_Other

$\mathrm{Xu}$, Zhun. (2018). From Commune to Capitalism: How China's Peasants Lost Collective Farming and Gained Urban Poverty. New York: Monthly Review Press.

Xu, Zhun. (2013). The Political Economy of Decollectivization in China. Monthly Review, 65 (1). 